Romanyshyn, Y., Temnyk, I., \& Lapovets, L. (1999). Metodychni rekomendatsii dlia otsinky imunnoho statusu liudyny: vyznachennia pokaznykiv klitynnoho imunitetu: metod. rekomendatsii. Lviv: SPOLOM (in Ukrainian).

Vlizlo, V., Fedoruk, R., \& Ratych, I. (2012). Laboratorni metody doslidzhen u biolohii, tvarynnytstvi ta veterynarnii medytsyni: dovidnyk. Lviv: SPOLOM (in Ukrainian).

Zasukha, Y., Nahaievych, V., \& Khomenko, M. (2006). Tekhnolohiia vyrobnytstva produktsii svynarstva. Vinnytsia: Nova Knyha (in Ukrainian).

Instruktsii z vykorystannia diahnostykumiv erytrotsytarnykh dlia vyiavlennia populiatsii T-limfotsytiv: Anty- SD3, AntySD4, Anty- SD8, Anty- SD16, Anty- SD22. Kharkiv: Hranum. Retrieved from: granum@granum.com.ua (in Ukrainian)

\title{
CHARACTERISTICS OF MICROBIOLOGICAL PARAMETERS OF THE FROZEN FISH IN THE PRESENCE OF ANTIBIOTIC RESIDUES
}

\author{
Z. V. Malimon \\ State Research Institute for Laboratory Diagnostics and Veterinary and Sanitary Expertise \\ Donetska, Str., 30, Kyiv, Ukraine, 02000, E-mail: z malimon@ukr.net \\ ORCID 0000-0002-8616-3198
}

\begin{abstract}
Due to its high nutritional and biological value, fish is a good nutrient for development of microorganisms, therefore, the conditions and terms of its storage require appropriate temperature regimes to stop the growth of microflora. The work aimed at determining the microbiological parameters of frozen fish, which according to biochemical parameters was designated as stale, depending on the presence of antibiotic residues. In samples, we studied mesophilic microorganisms at temperature $(30 \pm 1)^{\circ} \mathrm{C}$ incubation of crops during 72 hours and psychrotrophic microflora at temperature $(6.5 \pm 0.5){ }^{\circ} \mathrm{C}$ incubation - during 10 days. Bacteria of the colibacillus group were determined in Endo and Kesler's medium, and staphylococcus aureus in saline haemo-agar. Biochemical parameters: reaction with copper sulfate, peroxidase, $\mathrm{pH}$ was determined using generally accepted methods, total volatile content of nitrogen is in accordance with EU Regulation 2027/2005. Presence of antibacterial residues was determined using microbiological and immuno-enzymatic methods

It was established that samples of frozen fish which according to the biochemical parameters designated it as stale, as well as absence of antibacterial residues in the flesh, were mainly contaminated by psychotrophic microflora in the amount of over $1 \mathrm{mil} \mathrm{CFU/g}$. According to the content of colibacillus group the number of fish samples which fit the standard (up to 1 thousand CFU/g or absence in $0,001 \mathrm{~g}$ of the product) was $4.8 \pm 0.2 \%$, and according to the content of staphylococcus aureus it was $9.7 \pm$
\end{abstract}

$0,3 \%$ (standard up to $100 \mathrm{CFU} / \mathrm{g}$ or absence in $0.01 \mathrm{~g}$ of the product). Number of tests according to the content of coliforms, which exceeded 10 thousand CFU/g, was $88.7 \pm 3.4 \%$, which is 5.8 times $(p<0,05)$ more than number of samples with such a content of staphylococcus aureus. Stale frozen fish, according to biochemical parameters, produced staphylococcus aureus in the amount from 1 thousand to 10 thousand CFU/g in $62,1 \pm 2,7 \%$ of cases. It was established that number of fish samples designated as poor quality ones according to their biochemical parameters, but which according to the content of antibiotics, according to the content of mesophilic microflora met standard requirements were in average 14 times $(p<0.05)$ more compared with the fish samples without antibiotic residues. It was revealed that according to the contents of bacteria of colicacilus group and Staphylococcus aureus this fish in $90,9 \pm 2,7 \%$ of samples met the requirements of ISO, which correspondently is 18.9 and 9.3 times $(p<0.05)$ more compared to such fish without antibiotics. It was proved that quantitatively psychrotrophic microflora of the frozen fish exceeds the amount of MAPANM and more fully characterizes biochemical processes which determine its freshness. Thus, only comprehensive control of frozen fish imported into Ukraine, including biochemical, microbiological parameters and presence of antibacterial residues will allow to detect and eliminate dangerous products.

Key words: fish, contamination, psychotropic, mesophilic microflora, biological parameters.

\section{ХАРАКТЕРИСТИКА МІКРОБІОЛОГІЧНИХ ПОКАЗНИКІВ ЗАМОРОЖЕНОЇ РИБИ ЗА НАЯВНОСТІ ЗАЛИШКІВ АНТИБАКТЕРІАЛЬНИХ ПРЕПАРАТІВ}

\section{3. В. Малімон}

Державний науково-дослідний інститут з лабораторної діагностики та ветеринарно-санітарної експертизи вул. Донецька, 30, м. Київ, Україна, 02000; E-mail: z malimon@ukr.net

ORCID 0000-0002-8616-3198

Встановлено, що проб неякісної риби за біохімічними показниками, але з вмістом антибактеріальних препаратів, яка за вмістом МАФАнМ відповідала стандартним вимогам було у середньому, в 14 разів більие, порівняно з такою рибою без залишків антибіотиків. Виявлено, що за вмістом БГКП $і$ золотистого

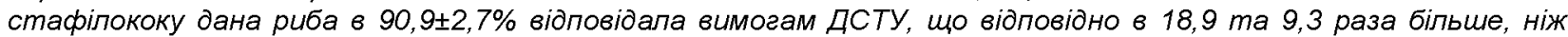
риба без вмісту антибактеріальних препаратів. 


\section{Вступ}

Рибу відносять до швидкопсувних харчових продуктів, які вимагають відповідних температурних режимів зберігання для зупинення перебігу біохімічних і мікробіологічних процесів. На український ринок морську рибу доставляють, в основному, у замороженому вигляді за температури - 12 - - $18{ }^{\circ} \mathrm{C}$. При недотримані технології холодильного ланцюга, риба швидко псується i може бути джерелом харчових інфекцій та токсикозів.

Аналіз останніх досліджень ; публікацій. Згідно з ДСТУ 4868:2007 Риба заморожена. Технічні умови (Riba samorozhena. Technitschni umowi, 2007) у рибі регламентують такі мікробіологічні показники: кількість МАФАнМ (мезофрільні аеробні та факультативно- анаеробні мікроорганізми) до 50 тис. КУО/Г; бактерії групи кишкових паличок (БГКП) не дозволені в 0,001 г риби; золотистий стафрілокок у 0,01 г; патогенні мікроорганізми, у т.ч. роду Salmonella та Listeria monocytogenes відсутні у 25,0 г та відсутній Vibrio parahaemolyticus у 1,0 г.

У той же час, у наукових публікаціях (Mulic, Giljanovic, Ropac, \& Katalinic, 2004; Zambuchini, Fiorini, Verdenelli, \& Orpianesi, 2008) вчені, в основному, звертають увагу на обсіменіння замороженої риби МАФАнМ та БГКП. У неохолодженій рибі та морепродуктах переважає мезофільна аеробна і фракультативно-анаеробна мікрофлора (Ercolini, Russo, Nasi, Ferranti, \& Villani, 2009). У той же час, за їхнього зберігання в умовах холодильних камер домінуе холодолюбива психротрофна мікрофлора, яка, за даними багатьох вчених, спричиняє біохімічні та органолептичні зміни в рибі та впливає на санітарно-гігієнічні показники (Mulic, Giljanovic, Ropac, \& Katalinic, 2004; Topic Popovic et al., 2010; Salata, \& Kuchtin, 2017). Так дослідники (Chouliara, Savvaidis, Panagiotakis, Kontominas, 2004; Salata, Kukhtyn, Semanjuk, \& Perkij, 2017) вказують, що при недотриманні температурних режимів зберігання риба швидко псується внаслідок розвитку грамнегативних неферментуючих психротрофних мікроорганізмів, в основному, родів Pseudomonas spp. Дослідження 3 визначення обсіменіння замороженої риби психротрофною мікрофлорою нормативноправовими вимогами не передбачено.

Крім того, нині в галузі рибництва для лікування та профілактики різних хвороб широко застосовують антибактеріальні препарати (Grynevych et al., 2018). Безконтрольне використання антибактеріальних препаратів, призводить до накопичення їх у рибі і морепродуктах (Akinbowale, Peng, \& Barton, 2006; Bayer, Novozhitskaya, Shevchenko, \& Mykhalska, 2017). Однак згідно із «Планом державного моніторингу залишків ветеринарних препаратів та забруднювачів у живих тваринах i необроблених харчових продуктах тваринного походження» визначення залишкових кількостей ветеринарних препаратів передбачається тільки у рибі українського виробництва. У замороженій рибі, яка імпортується в Україну, визначення наявності залишкових кількостей антибактеріальних препаратів не проводиться.

Отже, враховуючи вище наведене, проведення досліджень 3 визначення мікробіологічних показників замороженої риби, яка імпортується в Україну, зокрема обсіменіння психротрофнню мікрофолорою, залежно від біохімічних показників якості та наявності залишків антибактеріальних препаратів $є$ актуальним.

Memoю роботи було визначити мікробіологічні показники замороженої риби, яка за біохімічними показниками відносилася до несвіжої, залежно від наявності залишків антибактеріальних препаратів.

Завдання дослідження: охарактеризувати заморожену рибу за вмістом МАФАнМ, психротрофної мікрофлори, БГКП і золотистого стафрілококу, яка за біохімічними показниками відносилися до несвіжої риби та за відсутності залишків антибактеріальних препаратів; охарактеризувати заморожену рибу за вмістом кМАФАнМ, психротрофної мікрофллори, БГКП і золотистого стафрілококу, яка за біохімічними показниками відносилися до несвіжої риби, але в ній було виявлено залишки антибактеріальних препаратів

\section{Матеріали і методи досліджень}

Робота виконана в Державному науководослідному інституті з лабораторної діагностики та ветеринарно-санітарної експертизи (ДНДІЛДВСЕ) та в Тернопільській дослідній станції Інституту ветеринарної медицини НАAН.

Досліджено 77 проб замороженої риби за мікробіологічними і біохімічними показниками. Проби замороженої риби відбирали і підготовлювали для мікробіологічних досліджень згідно 3 ДСТУ 4868:2007. У пробах визначали МАФАнМ за температури $(30 \pm 1){ }^{\circ} \mathrm{C}$ при інкубації посівів упродовж 72 години та психротрофну мікрофрлору за температури $(6,5 \pm 0,5){ }^{\circ} \mathrm{C}$ при інкубації упродовж 10 діб (Salata, \& Kuchtin, 2017). БГКП визначали на середовищі Ендо та Кеслер, а золотистий стафілокок на сольовому емо агарі. Біохімічні показники: реакція з сірчанокислою міддю, на пероксидазу, визначення $\mathrm{pH}$ проводились згідно з ДСТУ 7992:2015, кількість загальних летких основ азоту згідно Регламенту ЕC 2027/2005. Наявність залишків антибактеріальних препаратів у замороженій рибі визначали мікробіологічним та імуноферментним методами.

Статистичну обробку результатів дослідження здійснювали за загальновизнаними методами варіаційної статистики 3 використанням програми Statistic 6. Різницю між порівнюваними величинами вважали достовірною при $p \leq 0,05$.

\section{Результати та їх обговорення}

Попередніми нашими дослідженнями встановлено, що при задовільних біохімічних показниках замороженої риби та за відсутності в ній залишків антибактеріальних препаратів, виявляється від 25 до $50 \%$ проб з понаднормативним (більше 50 тис. КУО/г) вмістом МАФАнМ. Також виявлено, що у даних пробах кількість психротрофнних мікроорганізмів у $70 \%$ випадків переважав показник у 50 тис. КУО/г. Тому нами було проведено визначення обсіменіння замороженої риби мезофрільною і психротрофною мікрофлорою, яка за показниками реакцій з сірчанокислою міддю, на пероксидазу, на вміст загальних летких основ азоту та $\mathrm{pH}$, відносилися до сумнівної та несвіжої. При цьому у даних пробах риби не виявляли залишки антибактеріальних препаратів. Результати наведено на рис. 1. 


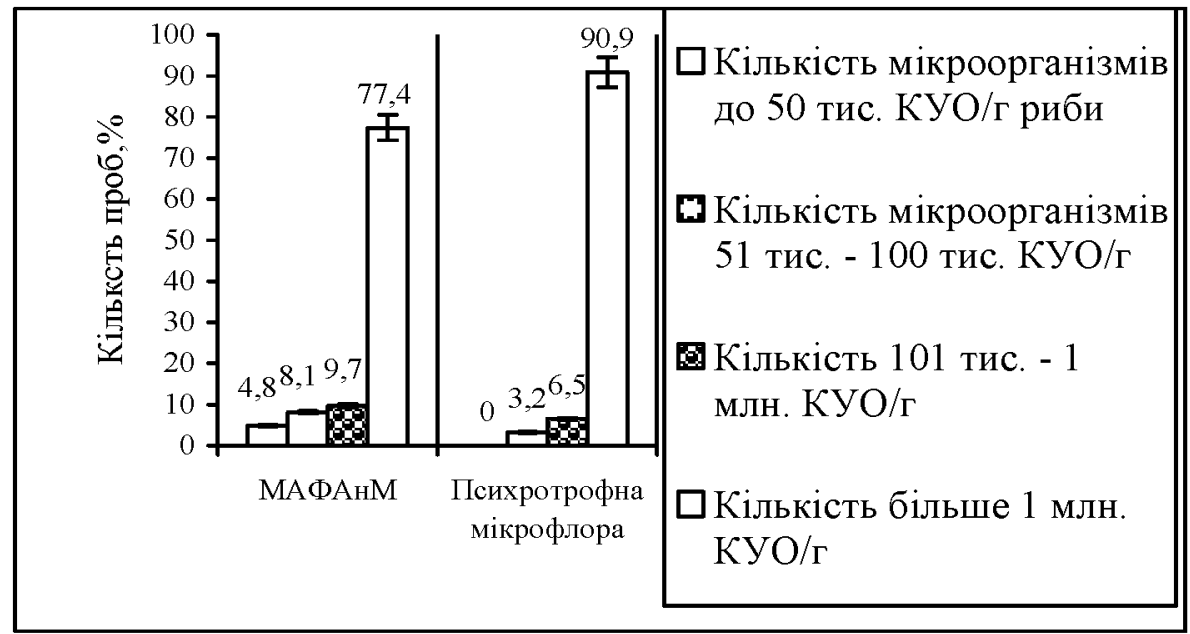

Рис. 1. Розподіл проб замороженої риби за вмістом МАФАнМ і психротрофної мікрофлори, які за біохімічними показниками відносилися до несвіжої риби за відсутності в ній залишків антибактеріальних препаратів

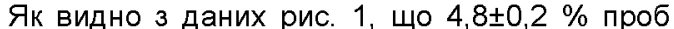
замороженої риби були контаміновані мезофільною мікрофрлорою до 50 тис. КУО/г, тобто вкладалися у норматив згідно з ДСТУ. Проте основна кількість $77,4 \pm 2,1 \%$ проб замороженої риби, які за біохімічними показниками відносилися до несвіжої, були контаміновані МАФАнМ, яка перевищувала 1 млн. КУО//г. Обсіменіння психротрофною мікрофрлорою даної риби виявилося кількісно більшим. Так проб з вмістом психротрофів до 50 тис. КУО/г взагалі не виявлялося, а до $1 \mathrm{mлн.} \mathrm{КУО/г} \mathrm{в} \mathrm{1,8}$ рази $(p<0,05)$ менше, порівняно $з$ кількістю
МАФАнМ. Практично основна частина замороженої риби $(90,9 \pm 2,7 \%$ проб) була контамінована психротрофною мікрофлорою, яка переважала кількість 1 млн. КУО/г. Власне при порушенні технологічних режимів заморожування, транспортування та зберігання і відбувається ії розвиток, тому біохімічні вади такої риби пов'язані з розвитком цієї групи мікрофолори.

На рис. 2 наведено результати досліджень щодо обсіменіння цих же проб замороженої риби БГКП і золотистим стафрілококом.

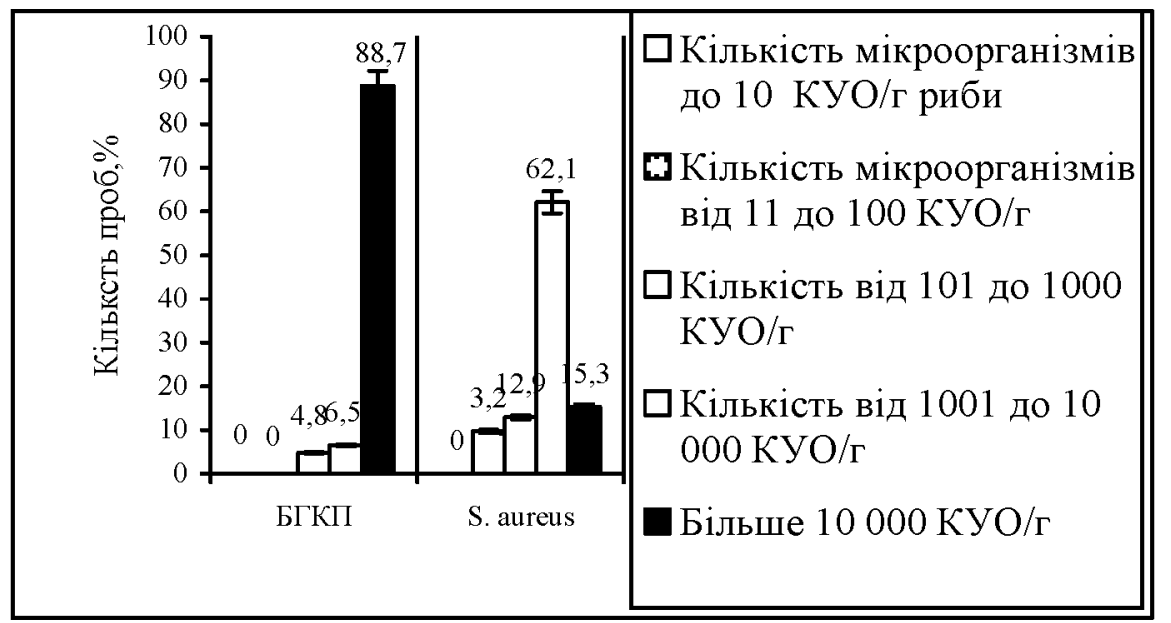

Рис. 2. Розподіл проб замороженої риби за вмістом БГКП і золотистого стафілококу, які за біохімічними показниками відносилися до несвіжої риби за відсутності в ній залишків антибактеріальних препаратів

Санітарно-показові мікроорганізми БГКП і золотистий стасрілокок, які регламентуються у ДСТУ, також виділялися у значній кількості із несвіжої риби без вмісту залишків антибактеріальних препаратів. При цьому за вмістом БГКП, кількість проб риби, які вкладалися у стандартний норматив (до 1 тис. КУО/Г або

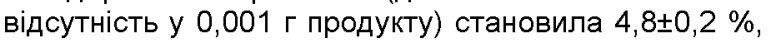
а за вмістом золотистого стафілококу $9,7 \pm 0,3 \%$ (норматив до $100 \mathrm{KVO} / г$ або відсутність у 0,01 г продукту). Кількість проб за вмістом БГКП, яка переважала 10 тис. КУО/г, становила $88,7 \pm 3,4 \%$, що в 5,8 раза $(\mathrm{p}<0,05)$ більше, ніж проб з таким вмістом золотистого стафрілококу. В основному, 3 несвіжої замороженої риби за біохімічними показниками, виділявся золотистий стафрілокок в

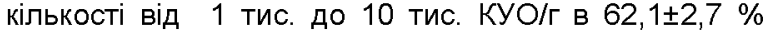
випадків.

Отже, отримані результати вказують, що недоброякісна за біохімічними показниками

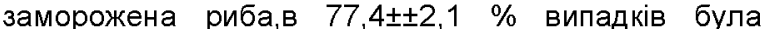
контамінована МАФАнМ і в $90,9 \pm 2,7$ \% випадків психротрофною мікрофлорою, яка переважала кількість 1 млн. КУО/г, вміст же БГКП становив 
більше 10 тис. КУО/г у 88,7士3,4\% досліджених проб. Ймовірно, саме з цими мікроорганізмами пов'язані біохімічні зміни у м'ясі риби.

Другою частиною наших досліджень було визначити мікробіологічні показники замороженої риби, яка за біохімічними показниками відносилися до сумнівної та несвіжої, але містила залишки антибактеріальних препаратів.
На рис. 3 наведено результати досліджень щодо обсіменіння замороженої риби мезофрільною і психротрофною мікрофлорою, яка за показниками реакцій з сірчанокислою міддю, на пероксидазу, на вміст загальних летких основ азоту та $\mathrm{pH}$, відносилися до сумнівної та несвіжої, але із вмістом залишків антибактеріальних препаратів.

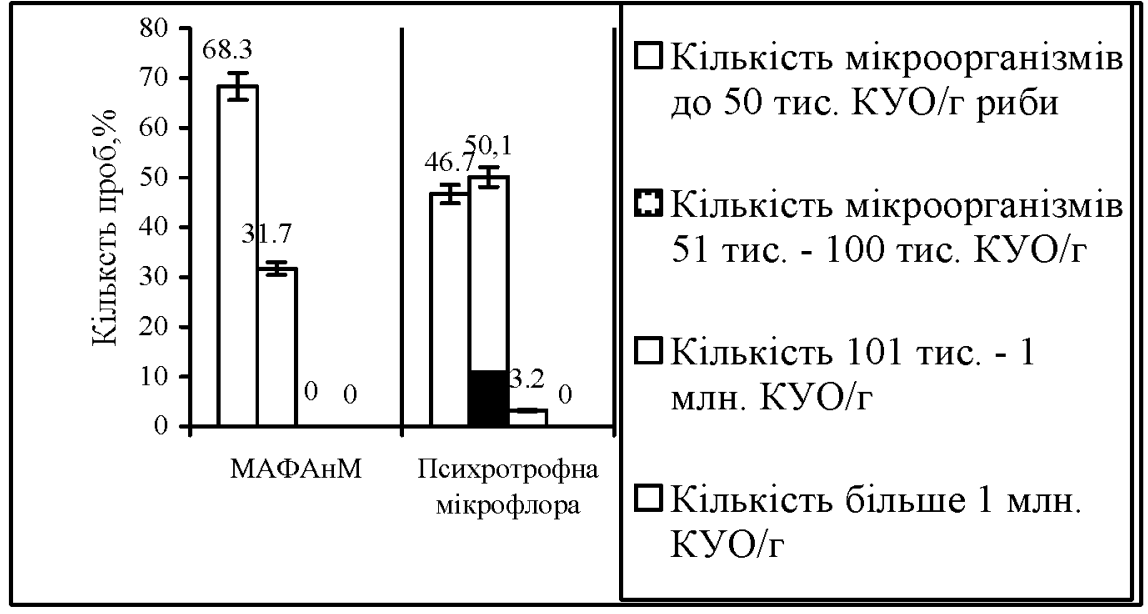

Рис. 3. Розподіл проб замороженої риби за вмістом МАФАнМ і психротрофної мікрофлори, які за біохімічними показниками відносилися до не свіжої риби, але містили залишки антибактеріальних препаратів

3 даних рис. 3 видно, щуо кількість проб замороженої риби за вмістом МАФАнМ, яка вкладалася у визначений ДСТУ норматив до 50 тис. КУО/г становила $68,3 \pm 2,9 \%$, в решті ж проб - не перевищувала кількість у 100 тис. КУО/г. За вмістом психротрофної мікрофлори відмічаємо зменшення в 1,5 раза $(\mathrm{p}<0,05)$ кількості проб із показником до 50 тис. КУО/г та зростання в 1,6 раза $(\mathrm{p}<0,05)$ проб із рівнем обсіменіння - до 100 тис. КУО/г, порівняно 3 мезофрільною групою мікрофлори. Також виявлено $3,2 \pm 0,2 \%$ проб з вмістом психротрнофів, які перевищували 100 тис. КУО/г.

Загалом 3 отриманих даних видно, що неякісна риба за біохімічними показниками, але 3 вмістом антибактеріальних препаратів за показником МАФАнМ відповідала стандартним вимогам, у середньому, в 14 разів $(p<0,05)$ більше, порівняно 3 такою рибою без залишків антибактеріальних препаратів. Отже, результати досліджень вказують на те, що залишки антибактеріальних препаратів, які наявні в замороженій рибі, гальмують розвиток мікрофлори. Разом з тим виявлено, що психротрофна мікрофлора більш чисельно представлена у складі мікрофлори замороженої риби. Виникнення біохімічних змін у замороженій рибі за наявності залишків антибактеріальних препаратів, ймовірно пов'язане з процесами автолізу під впливом нативних ензимів.

Аналогічні закономірності змін отримали і за обсіменіння замороженої риби БГКП і золотистим стафрілококом 3 вмістом антибактеріальних препаратів (рис. 4).

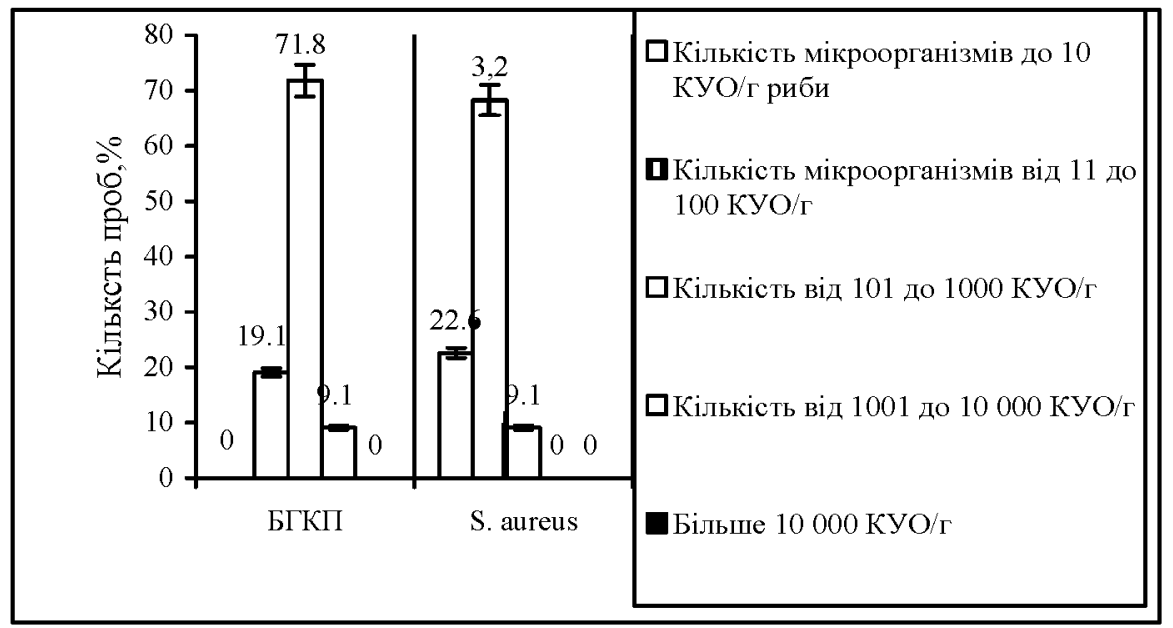

Рис. 4. Розподіл проб замороженої риби за вмістом золотистого стафрілококу і БГКП, які за біохімічними показником відносилися до несвіжої риби, але містили залишки антибактеріальних препаратів. 
Виявлено, що за вмістом БГКП і золотистого

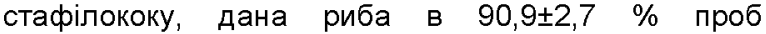
відповідала вимогам ДСТУ, що в 18,9 та 9,3 раза ( $<0,05$ ) відповідно більше, порівняно з такою рибою без вмісту антибактеріальних препаратів (рис 2).

\section{Висновки}

1. Встановлено, що досліджені проби замороженої риби, які за біохімічними показниками відносилися до несвіжої, але не містили залишки антибактеріальних препаратів, у 95,2 $22,7 \%$ випадків за вмістом МАФАнМ не відповідають вимогам ДСТУ, а за вмістом психротрофів всі $100 \%$ проб не відповідали цьому рівню. За вмістом БГКП, кількість проб риби, які вкладалися у стандартний норматив становила $4,8 \pm 0,2 \%$, а за вмістом золотистого стафрілококу $9,7 \pm 0,3 \%$.

2. Заморожена риба, яка за біохімічними показниками відносилася до несвіжої, але містила залишки антибактеріальних препаратів, у 68,3ะ2,9\% випадках за вмістом МАФАнМ відповідала вимогам стандарту. Санітарно-показові мікроорганізми (БГКП і золотистий стафілокок) у замороженій рибі із вмістом залишків антибактеріальних препаратів також виділялися в значно меншій мірі, порівняно з рибою без антибіотиків.

3. Виявлено, що кількість психротрофної мікрофолори замороженої риби перевищує вміст МАФАнМ і більш повно характеризує біохімічні процеси, які визначають ії свіжість. Тільки комплексний контроль замороженої риби, яка імпортується в Україну, за біохімічними, мікробіологічними показниками та визначенням залишків антибактеріальних препаратів дозволить виявити і вибракувати небезпечну продукцію.

Перспективи подальиих досліджень полягають у вивченні родового і видового складу психротрофної мікрофлори, залежно від вмісту залишків антибактеріальних препаратів та біохімічних показників, які характеризують її якість.

\title{
References
}

Akinbowale, O. L., Peng, H., \& Barton, M. D. (2006). Antimicrobial resistance in bacteria isolated from aquaculture sources in Australia. Journal of Applied Microbiology, 100, 5, 1103-1113.

Bayer, E. V., Novozhitskaya, Yu. N., Shevchenko, L. V., \& Mykhalska, V. M. (2017). Monitoring of residues of veterinary preparations in food products. Ukrainian Journal of Ecology, 7, (3), 251-257. doi: 10.15421/2017_76

Chouliara, I., Savvaidis, I. N., Panagiotakis, N., Kontominas, M. G. (2004). Reservation of salted, vacuum-packaged, refrigerated sea bream (Sparus aurata) fillets by irradiation: microbiological, chemical and sensory attributes. Food Microbiology, 21, 351-359.

Ercolini, D., Russo, F., Nasi, A., Ferranti, P., \& Villani, F. (2009). Mesophilic and Psychrotrophic Bacteria from Meat and Their Spoilage Potential In Vitro and in Beef. Applied and environmental microbiology, 75, 1990-2001.

Grynevych, N., Sliusarenko, A., Dyman, T., Sliusarenko, S., Gutyj, B., Kukhtyn, M. .. Kushnir, V. (2018). Etiology and histopathological alterations in some body organs of juvenile rainbow trout Oncorhynchus mykiss (Walbaum, 1792 ) at nitrite poisoning. Ukrainian Journal of Ecology, 8, 1, 402-408. doi: 10.15421/2018_228

Mulic, R., Giljanovic, S., Ropac, D., \& Katalinic, V. (2004). Some epidemiologic characteristics of foodborne intoxications in Croatia during the 1992-2001 period. Acta Medica Croatica, 58, 421-427.

Riba samorozhena. Technitschni umowi. (2007). HOST 4868:2007 from 01th January 2008. Kiev Nazional'nij ctandart Ukraïni (in Ukrainian)

Salata, W. S., \& Kuchtin, M. D. (2017). Mikrovlora ocholodzhenoi i primorozhenoi jalowitschini sa cholodil'nogo sberigannja. Problemy zooinzhenerii ta veterynarnoi medytsyny: Zbirnyk naukovykh prats Kharkivskoi derzhavnoi zooveterynarnoi akademii, 2, 34, 332-336 (in Ukrainian).

Salata, W. S., Kukhtyn, M. D., Semanjuk, V. I., \& Perkij, Y. B. (2017). Dynamika mikroflory okholodzhenoi i prymorozhenoi yalovychyny za yii zberihannia. Naukovyi visnyk Lvivskoho natsionalnoho universytetu veterynarnoi medytsyny ta biotekhnolohii im. S. Z. Hzhytskoho, 19, 73, 178-182. (in Ukrainian).

Topic Popovic, N., Benussi Skukan, A., Dzidara, P., Coz-Rakovac, R., Strunjak-Perovic, I., Kozacinski, L. ... BrlekGorski, D. (2010). Microbiological quality of marketed fresh and frozen seafood caught off the Adriatic coast of Croatia. Veterinarni Medicina, 55, 5, 233-241.

Zambuchini, B., Fiorini, D., Verdenelli, M. C., \& Orpianesi, C. (2008). Inhibition of microbiological activity during sole (Solea solea L.) chilled storage by applying ellagic and ascorbic acids. Food Science and Technology, 41, 17331738 .

\section{ADVANCEMENT OF THE METHOD OF NON-COMBINED DEFINITION OF NON-MIOCYIN IN CHARACTERISTICS THE METHOD OF IMMUNOFERMAL ANALYSIS}

\author{
K. S. Myagka', S.A.Tkachuk² \\ ${ }^{1}$ State Research Institute with laboratory diagnostics and veterinary-sanitary expertise Expertise, Kyiv, Ukraine \\ E-mail: katerina miagka@meta.ua \\ ${ }^{2}$ National University of Life and Environmental Sciences of Ukraine, Kyiv, Ukraine, \\ E-mail: ohdin@ukr.net
}

Improving the methods for detecting antibiotics, in particular from the class of aminoglycosides, is an actual problem of modern laboratory work for the purpose of carrying out state control over their content in honey 